\title{
トリクロロエチレンの水-固形廃衰物間の分配係数測定法について
}

\author{
李 東 勲* 田中信 寿* 神 山桂 -*
}

\section{On the Method for Determining Partition Coefficient of Trichloroethylene in Water-Solid Waste System}

\author{
Donghoon LEE*, Nobutoshi TANAKA* and Keiichi KOYAMA*
}

* Dept. of Environmental and Sanitary Eng., Hokkaido Univ., Nishi-8, Kita-13, Kita-ku, Sapporo, 060

\section{1.はじめに}

トリクロロエチレン (以下 TCE) のよらな非イオン 性有機化合物によって地下水扣よび地表水が広く污染 されていることが，多数報告され 1 ， また，米国および ヨーロッパなどでは廃棄物埋立地の浸出水からも多種 の非イオン性有機化合物が検出されたとの報告があ る2)。日本でも不然ごみ埋立処分場の表層土畩中気相 から検出されたとの報告がある3)。従って, 非イオン性 有機化合物の土壌, 底質, 廃棄物中での挙動を解明す ることが重要である。このような挙動を考える上で重 要な現象の 1 つは水中に存在する非イオン性有機化合 物が固形物に収着する現象であり4)，これを記述する ためには分配係数を求める必要がある。土壌や底質に 対するこれまでの研究では，収着剤中有機物量あるい は有機炭素量当りに換算した分配係数 $\left(K_{O M}, K_{O C}\right)$ が, 土壤，底質に対して収着質の種類ごとに一定の値を取 ることを利用して，大略，分配係数を求め得ると報告 されている5)。しかし, 固形廃棄物に対しては, 著者ら が前報6)で報告しているように, $K_{O M}$ が固形廃棄物の種 類ごとに異なった値を取って和り, 結局, $K_{P}$ を収着質 と収着剂の組み合わせごとに実験的に求めざるを得な いことになる。従って，簡便に $K_{P}$ を求める実験法が必 要となる。これまで使用されてきた分配係数測定法は, 収着平衡後に固液分離（遠心分離，沪過，沈殿など） して得た水中の収着質濃度を測定する方法(以下では, この方法を水中濃度分析法という）である。しかし，
この方法には，不完全な固液分離，すなわち、コロイ ド，あるいは微粒性収着剤による収着などによる誤差 (いわゆる“solid effect”) が生ずる欠点があると指摘 する報告が見られる7)。

最近, Garbarini ら ${ }^{8)}$ は, この欠点を解決するために, 非イオン性有機化合物が揮発性である場合，それを利 用して，ヘンリー定数（気一液分配係数）が分かれば， 固液分離しなくても気相中の濃度を分析するのみで簡 単に分配係数を求める方法（以下では，ヘッドスペー ス分析法といら）を提案している。本論文では, 固形 廃棄物への分配係数測定に拈ける両法（水中濃度測定 法とヘッドスペース分析法）の比較検討について記述 する。

\section{2. 測 定 手 順}

TCE が低濃度 (ppb オーダー) で存在する場合には, 廃棄物への収着現象は, 次式で表現できる ${ }^{6}$ (この報告 では，水中濃度分析法を用いている)。

$$
S=K_{P} C_{L}
$$

ここで， $S$ は収着剂単位質量当りの平衡収着量 $[\mu \mathrm{g}$ ・ $\left.\mathrm{g}^{-1}\right], C_{L}$ は水中の平衡濃度 $\left[\mu \mathrm{g} \cdot \mathrm{m} l^{-1}\right]$ であり, $K_{P}$ は 分配係数 $\left[\mathrm{m} l \cdot \mathrm{g}^{-1}\right]$ である。水中濃度分析法による具 体的な測定手順は前報到に詳しく述べられているの で，ここでは簡単に説明することにとどめる。

密閉したバイアル中に収着質を含んだ水と収着剂を 入れ，定温条件で平衡に達するまで覺拌混合する。こ の場合, 気相を完全になくすことは物理的に不可能な

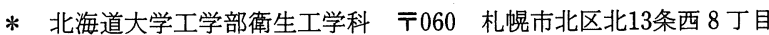


ので気相も存在する。気相および水相中の収着質濃度 を測定することにより，次式で $S$ が計算できる。

$$
\begin{aligned}
S=\{ & \left(C_{G 1} V_{G 1}+C_{L 1} V_{L 1}\right)-\left(C_{G 2} V_{G 2}\right. \\
& \left.\left.+C_{L 2} V_{L 2}\right)\right\} /\left\{M_{W}(1-W)\right\}
\end{aligned}
$$

ここで, $V_{G}$ 抢よび $V_{L}$ は気相揖よび水相の体積 $[\mathrm{m} l]$, $C_{\mathrm{G}}$ 扔よび $C_{L}$ は気相执よび水相の濃度 $\left[\mu \mathrm{g} \cdot \mathrm{m} l^{-1}\right]$, 添 字 1，2 はコントロール（収着剂の入っていないブラ ンク）扣よび収着剤の入っているものを示す。コント ロールは, 固液分離操作や栓を開けて水を取り出す際 に生ずる収着質の揮散などを補正するために必要であ る。 $M_{W}$ は収着剤の量 $[\mathrm{g}], W$ は収着剂中の含水率 $[\mathrm{g}$ ・ $\left.\mathrm{g}^{-1}\right]$ である。コントロールバイアルと収着剤量の異な るバイアルを複数でセットにして 1 回の実験を行い, $S$ と $C_{L}$ をグラフ上にプロットし,グラフ上の勾配から 式(1)の $K_{P}$ を決定する。な扔, JIS 0125-1987のへッド スペース法で水中の TCE 濃度を分析する時, 本論文 の溶存物濃度範囲内では分析值に対するサンプル液中 溶存物の影響のないことは確認した。

一方，ヘッドスペース分析法8)では，式(1)に加圥て, 次式で示す稀薄溶液に対するへンリー法則を利用す る。

$$
C_{G}=K_{H} C_{L}
$$

ここで, $K_{H}$ はへンリー定数(気一液分配係数)である。 式(1)と式(3)の成立を前提としてコントロールバイアル （添字 1) と収着剤添加バイアル（添字 2) について収 着質の物質収支をとると次のようになる。

$$
\begin{aligned}
M_{T}= & C_{G_{1}} V_{G_{1}}+C_{G_{1}} V_{L_{1}} / K_{H} \\
= & C_{G_{2}} V_{G_{2}}+C_{G_{2}} V_{L_{2}} /\left(\gamma K_{H}\right) \\
& +K_{P} C_{G_{2}} M_{W}(1-W) /\left(\gamma K_{H}\right)
\end{aligned}
$$

ここで, $M_{T}$ は密閉バイアルへ注入した収着質総量, $\gamma$ は収着実験条件でのヘンリ一定数補正係数である。

式(4)から式(5)を得る。

$$
\left(C_{G_{1}} / C_{G_{2}}\right)\left\{\gamma\left(V_{G_{1}} K_{H}+V_{L_{1}}\right) /\left(V_{G_{2}} \gamma K_{H}+V_{L_{2}}\right)\right\}
$$$$
=K_{P}\left\{M_{W}(1-W) /\left(V_{G_{2}} \gamma K_{H}+V_{L_{2}}\right)\right\}+1
$$

すなわち，式(5)を用いると， $\gamma K_{H}$ が確定していれば， 水中の濃度を測定しなくても, 気相中濃度 $C_{G}$ を測定す るのみで，K $K_{P}$ を決定することがでさる。ガスタイトシ リンジにより直接, ガス相から試料を採取できるので 密閉したバイアルを開放することなく測定できる。し たがって，この方法は水中濃度分析法に比べて極めて 簡便な方法であると言える。ただし，そのためには， $\gamma K_{H}$ が各種の測定条件に対して一定值であることが必 要である。

\section{3. 実験}

収着剂として使った材料は 2 つ清掃工場焼却炉の 灰ピットから採取した 2 種類の焼却灰 (ash C and ash
D）と前報6)で使ったものである。すなわち， 5 種類の 焼却灰 (ash A, B, C, D and landfilled ash), 破砕ご 及 (source separated and size reduced refuse, S.R. R.) 1 種類, 覆土 2 種類 (cover soil A and B), 人工 ごみ成分 (plastics, papers and wood), 砂 (sand), である。実験材料の特性や準備方法や TCE 分析方法 などは前報6を参照されたい。

\section{4.結果および考察}

\section{1 ヘンリー定数}

すべての収着実験に扔いて測定した液相（沈殿させ た後沪過で固液分離した沪液）抢よび気相の TCE 濃 度を用いてヘンリー定数を求め, $15,20,30^{\circ} \mathrm{C}$ での温 度別に頻度分布を求めた。ここでは，例として Fig.1 に $20^{\circ} \mathrm{C}$ の場合を示す。図中の 2 つのヒストグラムは, コントロール,すなわち, 純水に打ける $K_{H}$ 值の頻度分 布と同時に行った収着剤が添加されている場合の $K_{H}$ の頻度分布である。

収着剤を添加した場合はその水中の電解質および有 機物質として $\mathrm{Cl}^{-}$および DOC (溶存有機炭素) 濃度を 分析した。収着剤の種類ごとに違いがあるが，全体的 に約 $0 \sim 2,000 \mathrm{mgCl}^{-} ・ l^{-1}$ 执よび $0 \sim 700 \mathrm{mgDOC} \cdot l^{-1}$ の範囲であった。さらに，Fig. 1 に溶存物として $\mathrm{Cl}^{-1}$ が300 mg・ $l^{-1}$ 以上の場合に和ける $K_{H}$ 值の頻度分布を 示し, 溶存物量によるヘンリー定数への影響を他の 2 つの場合と比べてみた。この図から, 平均值 $(\overline{\mathrm{x}})$ と標 準偏差 (s) がほとんど一致し, 約 $300 \mathrm{mgCl}^{-1} \cdot l^{-1}$ $\sim 2,000 \mathrm{mgCl}^{-1}$ ・ $l^{-1}$ の範囲では溶存物が $K_{H}$ 値の頻度 分布に影響を与えていないことが分かる。また，溶存 物量の影響を示す例として, 最も高い溶存物濃度を示 した $\operatorname{ash} \mathrm{A}$ にいて添加収着剤量と $\mathrm{Cl}^{-}, \mathrm{DOC}$ 抢よび $K_{H}$ の変化を Fig。2 亿示した（KH の平均值を折れ線で 結び, 縦棒の長さで標準偏差を示した)。この図からも， $K_{H}$ 測定值の平均值は投入収着剂量ごとに注ぼ同じ值 を示し，このことからも溶存物質が $K_{H}$ の值に系統的 な差異を与党ることはないことがわかる。

以上のことから $K_{H}$ は本実験範囲内では純水のヘン リ一定数を用いて良い，すなわち，ヘンリー定数補正 值 $\gamma=1.0$ で良いことが分かった。

コントロールのヘンリー定数の平均值を温度に対し てプロットしたのが Fig. 3 である。この図上に既報の $25^{\circ} \mathrm{C}$ に抢けるへンリー定数 $0.397^{8)}$ 和よび $0.403^{9)}$ をプ ロットしてみるとほぼ一致しているのが分かる。しか し, 原因は分からないが, 安武ら ${ }^{10)}$ による標準状態での 気液分配係数とは, 該当温度に対して考光てみても相 当違うが, 温度増加に従って増加するヘンリー定数の 傾きは医ぼ一致している。 


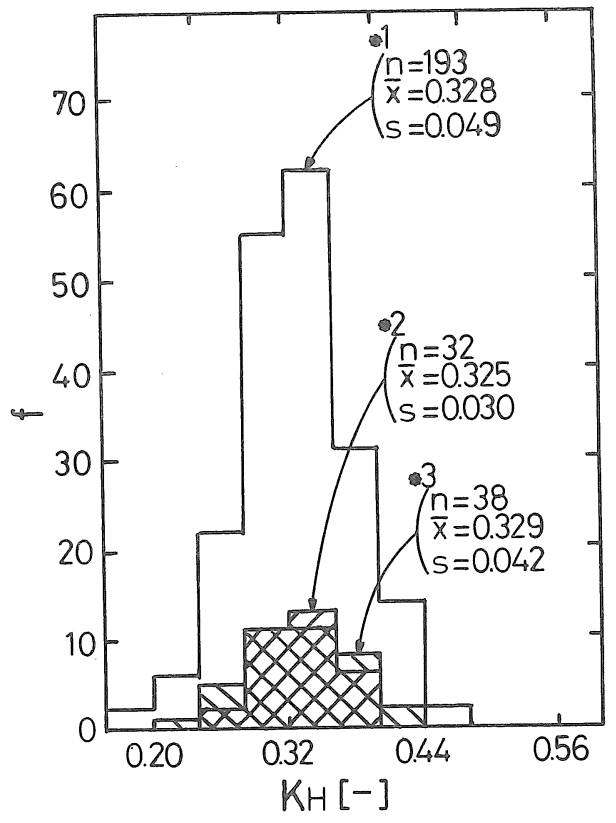

Fig. 1 Frequency distribution of Henry's law constants at $20^{\circ} \mathrm{C}{ }^{* 1}$ for all sorption experimental conditions ${ }^{* 2}$ for pure water ${ }^{* 3}$ for sorption experimental conditions over $300 \mathrm{mgCl}^{-} \cdot l^{-1}$ $n$; numbers of samples, $\bar{x}$; mean, $s$; standard deviation, $f$; frequency, $K_{H}$; Henry's law constant

\section{2 水中濃度分析法とヘッドスペース分析法によ \\ る結果比較}

前報で用いた水中濃度分析法では実験上生ずる揮散 等による損失によりデータがばらつく場合が見られ た。特にデータ数が少ない時や収着性が低い収着剂を 使った時にはその相関関係（実測值 $S$ と $C_{L}$ の線形関 係）の良くない場合がかなりあった。

ヘッドスペース分析法は実験条件下でのヘンリー定 数さ光確定できれば水中濃度分析法に比べて，実験過 程が非常に簡便であり，実験が完全密閉で行われるた め測定による誤差の発生する可能性が低いと思われ る。

Fig。4は例と乙て焼却灰 A と B 抢よび木片の等温 収着実験結果を両方法により計算し，同じ図上に表し たもので，Table1は両方法により求めた分配係数を 比較したものである。水中濃度分析法による分配係数 $K_{P}{ }^{a q}$ は Ash C とAsh D を除いて前報に示したもの で、ヘッドスペース法による分配係数 $K_{P}{ }^{h s}$ は水中濃度 分析の直前に分析した遠心管の気相の測定データを用 いて求めたものである。

Fig。4 に示すように，両方法の縦軸掞よび横軸の意

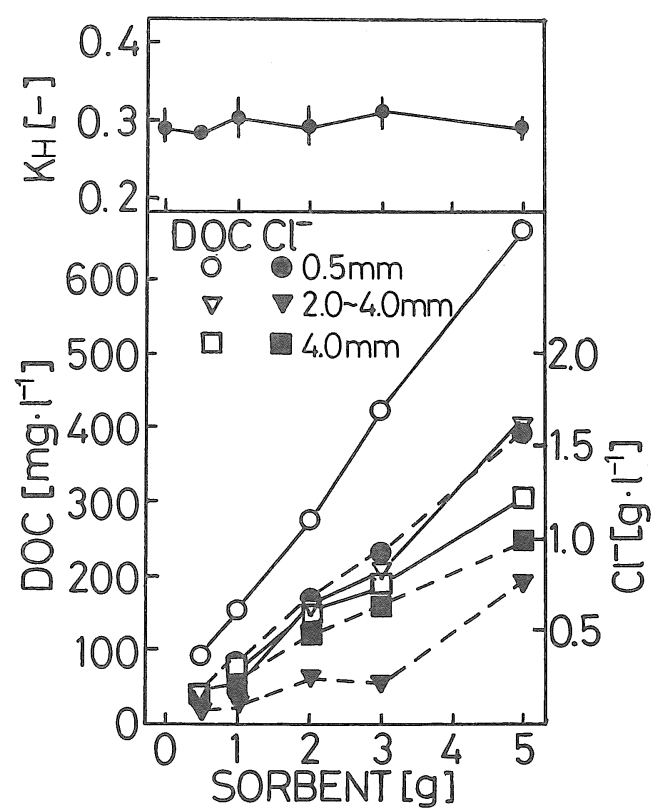

Fig. 2 Effect of dissolved organic carbon (DOC) and chloride concentration $\left(\mathrm{Cl}^{-}\right)$on Henry's law constant $\left(20^{\circ} \mathrm{C}\right.$, Ash A)

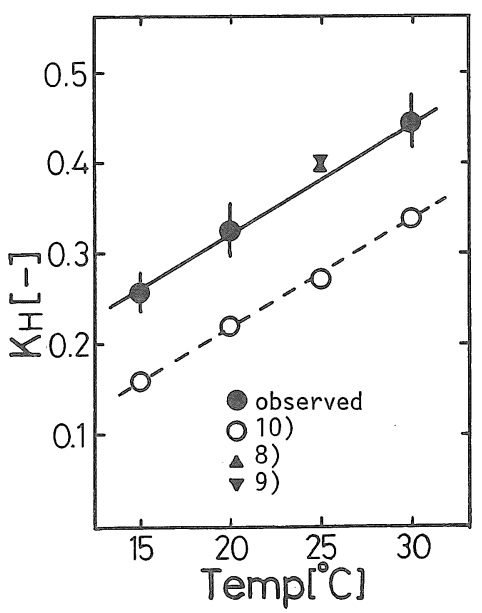

Fig. 3 Effect of temperature on Henry's law constant in pure water

味が違らが，見かけ上ほとんどすべての場合に拉いて ヘッドスペース分析法の方が水中濃度分析法よりも良 い直線的相関関係を持っていることが分かる。

Table 1 で， $K_{P}{ }^{a q}$ を比較してみると両者は大体一致 しているが，差が大きい場合もある。全般的に差が大 きい場合はへッドスペース分析法の線形性と比べて水 中濃度分析法の線形性が相対的に悪い場合に相当する ことが分かった。このように線形性が非常に悪かった 


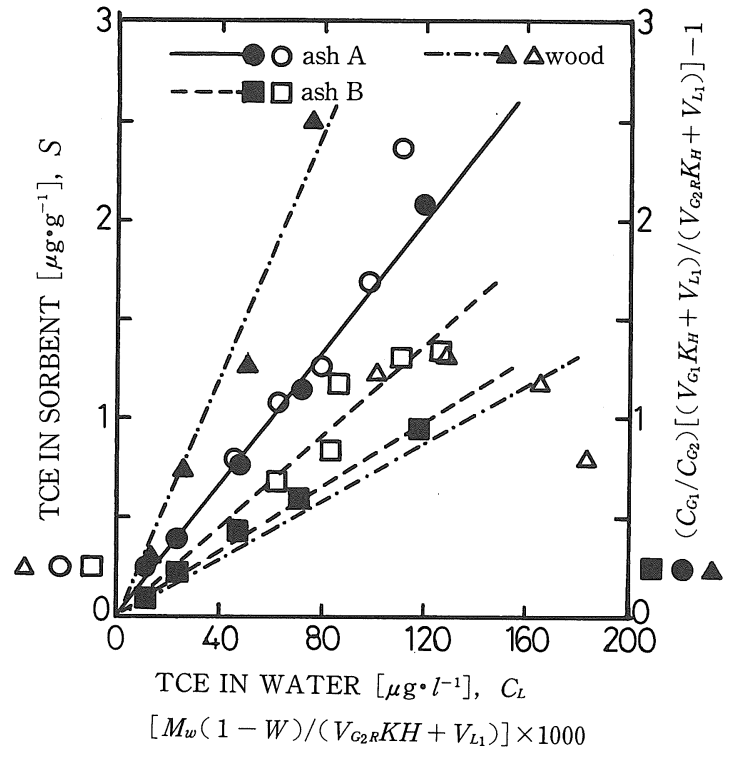

Fig. 4 Comparison of linearity between the headspace analysis method and the aqueous concentration analysis method for determining partition coefficient in the case of ash $\mathrm{A}$, ash $\mathrm{B}$ and wood $\left(20^{\circ}\right.$ C)

4 試料[段ボール，新聞紙，木片，埋立焼却灰 $(2.0 \sim 4.0$ $\mathrm{mm}$ ) ] と分配係数が非常に小さい覆土 $\mathrm{A}, \mathrm{B}$ 打よび砂 を除いた 30 試料に対して $K_{P}^{a q}$ と $K_{P}{ }^{h s} の$ 比を求め,

Table 1 に示した。その比の平均值は1.16(相対標準偏 差 $25 \%)$ で， $K_{P}^{a q}$ が $K_{P}{ }^{h s}$ より約 $16 \%$ 高く評価されてい る。この違いは水中濃度分析法が，分析手順上に大き い值を出しやすい特性を持っていることの表れである と思われる。以上述べたよらに，ヘッドスペース分析 法により分配係数を求める方法はヘンリー定数さえ確 認できれば水中濃度分析法より簡便で，良い直線性を 持つデータが得られることが分かった。

\section{5.おわりに}

揮発性, 非イオン性有機污染物質である TCEの水 一固形廃棄物間の分配係数測定法に関して従来の水中 濃度分析法と最近 Garbarini $5^{8)}$ が提案しているへッ ドスペース分析法を比較してみた。その結果，汪とん ぞ彼らの結論と一致しているが, 固形廃棄物に対して 得られた結果を改めてまとめると，次のようになる。

$1)$ 本実験で確認した範囲の収着実験条件 $\left(\mathrm{Cl}^{-}\right.$濃 度：0 2,000mg $\cdot l^{-1}$, DOC：0 700 mg $\cdot l^{-1}$ )下 でのヘンリー定数は, 純水の場合のそれと注ぼ一致す るので共存溶存物質による影響はないと思われる。

2 ）本実験で確認した約500 $\mu \mathrm{g} ・ l^{-1}$ あでの範团で は, ヘッドスペース分析法は水中濃度分析法よりも実
Table 1 Comparison of partition coefficients of TCE determined between by the headspace analysis method and by the aqueous concentration analysis method in water and solid wastes system $\left(20^{\circ} \mathrm{C}\right)$

\begin{tabular}{|c|c|c|c|c|c|c|c|c|c|}
\hline & Sorbents & $K_{p}^{h s}$ & $K_{p}^{a q *}$ & $K_{p}^{a q} / K_{p}^{h s}$ & & Sorbents & $K_{p}^{h s}$ & $K_{p}^{a q q}$ & $K_{p}^{a q} / K_{p}^{h s}$ \\
\hline \multirow{5}{*}{$\begin{array}{l}4 \\
\text { ज्ञ }\end{array}$} & $<0.5 \mathrm{~mm}$ & 16.8 & 17.0 & 1.01 & \multirow{5}{*}{ 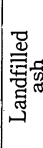 } & $<0.5 \mathrm{~mm}$ & 27.4 & 35.0 & 1.28 \\
\hline & $0.5-1.0 \mathrm{~mm}$ & 8.2 & 7.5 & 0.91 & & $0.5-1.0 \mathrm{~mm}$ & 11.9 & 12.3 & 1.03 \\
\hline & $1.0-2.0 \mathrm{~mm}$ & 4.8 & 8.5 & 1.77 & & $1.0-2.0 \mathrm{~mm}$ & 14.9 & 16.9 & 1.13 \\
\hline & \multirow{2}{*}{$\begin{array}{l}2.0-4.0 \mathrm{~mm} \\
<4.0 \mathrm{~mm}\end{array}$} & 9.1 & 10.5 & 1.15 & & $2.0-4.0 \mathrm{~mm}$ & \multicolumn{2}{|c|}{$8.5 \approx 15.8$} & - \\
\hline & & 10.8 & 11.6 & 1.07 & & $<4.0 \mathrm{~mm}$ & 23.0 & 20.5 & 0.89 \\
\hline \multirow{5}{*}{ 焉 } & $<0.5 \mathrm{~mm}$ & 8.1 & 11.4 & 1.41 & \multirow{5}{*}{ 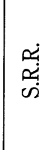 } & $<0.5 \mathrm{~mm}$ & 8.1 & 11.0 & 1.36 \\
\hline & $0.5-1.0 \mathrm{~mm}$ & 20.3 & 18.6 & 0.92 & & $0.5-1.0 \mathrm{~mm}$ & 8.2 & 11.8 & 1.44 \\
\hline & $1.0-2.0 \mathrm{~mm}$ & 19.3 & 20.6 & 1.07 & & $1.0-2.0 \mathrm{~mm}$ & 8.0 & 11.4 & 1.43 \\
\hline & $2.0-4.0 \mathrm{~mm}$ & 12.2 & 18.8 & 1.54 & & $2.0-4.0 \mathrm{~mm}$ & 7.3 & 10.3 & 1.41 \\
\hline & $<4.0 \mathrm{~mm}$ & 13.9 & 17.3 & 1.24 & & $<4.0 \mathrm{~mm}$ & 9.0 & 10.3 & 1.14 \\
\hline \multirow{3}{*}{$\begin{array}{l}0 \\
\text { 要 }\end{array}$} & $<0.5 \mathrm{~mm}$ & 57.1 & 70.0 & 1.23 & \multirow{3}{*}{ 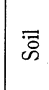 } & coversoilA & 0.9 & $\approx 0.9$ & - \\
\hline & \multirow[t]{2}{*}{$0.5-1.0 \mathrm{~mm}$} & \multirow[t]{2}{*}{62.8} & \multirow[t]{2}{*}{107.0} & \multirow[t]{2}{*}{1.70} & & \multirow{2}{*}{$\begin{array}{l}\text { coversoilB } \\
\text { sand }\end{array}$} & 0.6 & $\approx 0.5$ & - \\
\hline & & & & & & & 0.2 & $\approx 0.2$ & - \\
\hline \multirow{4}{*}{ 星 } & $<0.5 \mathrm{~mm}$ & 44.1 & 36.1 & 0.82 & \multirow{4}{*}{ 岕 } & corrugated & 11.6 & $\approx 6.6$ & - \\
\hline & $0.5-1.0 \mathrm{~mm}$ & 34.7 & 51.4 & 1.48 & & newspaper & 16.3 & $\approx 4.3$ & - \\
\hline & $1.0-2.0 \mathrm{~mm}$ & 14.3 & 20.5 & 1.43 & & milkpack & 12.3 & 11.4 & 0.93 \\
\hline & $2.0-4.0 \mathrm{~mm}$ & 6.7 & 5.9 & 0.88 & & & & & \\
\hline \multirow{2}{*}{ 좀. } & PE flim & 85.4 & 86.6 & 1.01 & \multirow{2}{*}{\multicolumn{2}{|c|}{ wood }} & \multirow[t]{2}{*}{26.0} & \multirow[t]{2}{*}{$\approx 7.3$} & \multirow[t]{2}{*}{-} \\
\hline & PVC tube & 361.5 & 237.3 & 0.66 & & & & & \\
\hline
\end{tabular}

$K_{p}^{h s}$ : TCE partition coefficient determined by headspace analysis method $\left[\mathrm{m} l \cdot \mathrm{g}^{-1}\right]$ $K_{p}^{a q}$ : TCE partition coefficient determined by aqueous concentration analysis method $\left[\mathrm{m} l \cdot \mathrm{g}^{-1}\right]$

- : not considered because $K_{p}^{a q}$ was determined approximately

*adapted from reference 6 except Ash C and Ash D

験データの処理において良い直線的相関関係を持つこ とを確認した。特に，KP $K_{P}$ 小さい場合には，ヘッドス ペース分析法の直線性が良かった。

3）以上のことと実験の簡便さを考え合わせると水 一固形廃棄物間に持けるトリクロロエチレンのような 揮発性, 非イオン性有機化学物質の分配係数を求める 方法はヘンリー定数が確認されていればヘッドスペー ス分析法がより良い方法である。

\section{6. 謝辞}

本研究に協力していただいた当講座 松尾孝之技官 および当学科卒業生 照山伸一君に深く感謝致しま す。

（原稿受理 1990年 1 月 17 日）

\section{参 考 文 献}

1）例点ば，環境庁水質保全局（1986）官公庁公害専門資料，21 (2), 65-69.

2 ) 例总ば, G.V. Sabel and T.P. Clark (1984) Volatile organic compounds as indicators of municipal solid waste leachate contamination, Waste Management \& Research, 2, 119-130. 3 ) 村岡浩爾, 平田健正 (1989) 有機塩素化合物の浸透・溶解実 験 と地下水污染機構, 第33回水理講演会論文集, 247-252.

4 ) 李 東勲, 田中信寿, 神山桂一 (1990) 廃棄物埋立層内に抒 
けるトリクロロエチレンの輸送現象に関する研究一湿潤廃棄 物中のガスによる輸送並びに飽和水による輸送一, 衛生工学研 究論文集, 26, 61-70.

5 ）例党ば, W.B. Neely (1980) Chemicals in the Environment, Marcel Dekker, N.Y., 49-51.

6 ）李 東勲, 田中信寿, 神山桂一 (1989) 埋立処分場廃棄物へ のトリクロロエチレンの収着特性について, 衛生工学研究論文 集, 25, 15-20.

7 ）例えば, D.J. O'Connor and J.P. Connolly (1980) The effect of concentration of adsorbing solids on the partition coeffi- cient, Water Research, 14, 1517-1523.

8 ) D.R. Garbarini and L.W. Lion (1985) Evaluation of sorptive partitioning of nonionic pollutants in closed systems by headspace analysis, Environmental Science and Technology, 19(11), 1122-1128.

9 ) D.T. Leighton and J.M. Calo (1981) J. of Chemical Engineering Data, 26, 382-385.

10）安武重雄, 有川彰浩, 槙田則夫, 三井康弘（1986）揮発性溶 存有機塩素化合物及び遊離炭酸除去用充填塔の設計因子の検 討, 水道協会雑誌, 55(12)，22-28. 


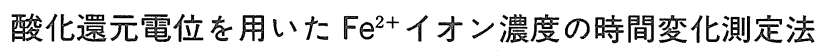

小林 節子* 西村 肇**

* 千葉県水質保全研究所 $* *$ 東京大学工学部化学工学科

〈水質污濁研究 Vol. 13 No.4（1990） pp.245 254〉

底質からのリンの溶出機構を解明する観点から, Fe(II)の酸化速度の測定法の検討を行った。ここでは, 吸光 度からの $[\mathrm{Fe}(\mathrm{II})]$ の測定が困難な高 $\mathrm{pH}$ 域での酸化速度を求める方法として, 溶液の酸化還元電位（ORP） の実測值 $\left(\mathrm{Eh}_{\mathrm{obs}}\right)$ を用いる方法を検討した。

結果は, $\mathrm{Fe}^{2+}-\mathrm{Fe}^{3+}$ の酸化還元反応に基づく溶液の ORP は, $\mathrm{Eh}=\mathrm{Eh}^{0}-0.05910 \mathrm{log}\left[\mathrm{Fe}^{2+}\right] /\left[\mathrm{Fe}^{3+}\right]$ (25ㅇ $\mathrm{C}$ で 表されるので, 生成した水酸化第二鉄が沈殿平衡にある時は, $\left[\mathrm{Fe}^{2+}\right]$ の時間変化は次式により予測できること が分かった。

$\log \left(\left[\mathrm{Fe}^{2+}\right]_{t=t} /\left[\mathrm{Fe}^{2+}\right]_{t=0}\right)=\left\{\left(\mathrm{Eh}_{\mathrm{obs}}\right)_{t=0}-\left(\mathrm{Eh}_{\mathrm{obs}}\right)_{t=t}\right\} / 0.059$

ここで，水酸化第二鉄の見かけの組成式として，実験から得られた $\left[\mathrm{Fe}^{3+}\right]\left[\mathrm{OH}^{-}\right]^{2.68}=10^{-35.8}$ をいた。

溶液の電位は時間経過と共に $\mathrm{NO}_{2}{ }^{-}-\mathrm{NO}_{3}$-系の酸化還元反応により決まるようになると考えられたことか ら, 得られた関係式を用いて 1 次式に基づく $\mathrm{Fe}(\mathrm{II})$ の酸化速度を求める際は, $\mathrm{Eh}_{\mathrm{obs}}$ が時間と共に直線的に増加 する部分を用いることが必要である。

\section{トリクロロエチレンの水-固形廃鰈物間の分配係数測定法について}

李 東勲* 田中 信寿* 神山 桂一*

* 北海道大学工学部

〈水質污濁研究 Vol. 13 No. 4 （1990） pp.255 259〉

日本での報告例は少ないが米国などの報告によると都市廃棄物埋立処分場の浸出水や近隣の地下水で揮発 性, 非イオン性有機化学物質が検出されている。ところが, 都市廃棄物埋立処分場に打けるこれらの物質に対 する研究は少ない。本研究では揮発性, 非イオン性有機化合物の一つとしてトリクロロエチレン (TCE) を対 象として, TCE の水-固形廃棄物間の分配係数を水中濃度分析法と最近 Garbarini らが提案しているへッドス ペース分析法で求め, 比較してみた。その結果, 固形廃棄物に対してもほとんど彼らの結論と一致している。 すなわち，上に述べた 2 つ方法によりそれぞれ求めた分配係数 $\left(K_{\mathrm{P}}\right)$ は医ぼ一致しているのでヘンリ一定数 が確認されていればヘッドスペース分析法の方がより簡便である。実験データの処理に打いて良い直線的相関 関係をもつため安定な $K_{\mathrm{P}}$ 值が求められる。特に, $K_{\mathrm{P}}$ 值の小さい場合には水中濃度分析法に比べ比較的安定な $K_{\mathrm{P}}$ 值が求められる。 